\title{
Thina Nzo
}

Local Government Public Affairs Research Institute

2 Sherwood Road

Parktown

Johannesburg

South Africa

Email: thina.nzo@gmail.com

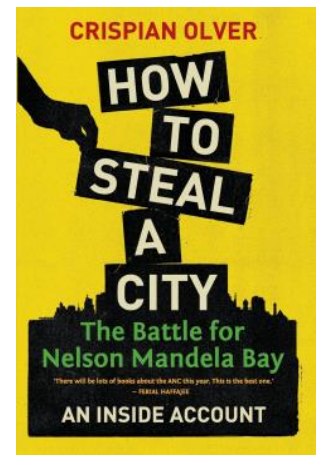

\section{How to Steal a City: The Battle for Nelson Mandela Bay an Inside Account by Crispian Olver}

The insider account of How to Steal a City undoubtedly is one of the few books that offers a much needed insight into the everyday workings of local government politics and administration in South Africa. This book is underpinned by rich descriptions of local government politics and administration generated through the personal experiences of Crispian Olver. Researchers, scholars, local politicians, municipal officials and practitioners of local government who wish to learn more about South African local government politics should have a good reason to pay close attention to this book. Since the African National Congress (ANC) came into power, it has enjoyed an overwhelming majority as the liberation party with its dominant grip over state institutions at national and subnational government level. Olver brings our attention to some of the unassailable hurdles of the configured dialectical relationship between ANC and the state from a subnational local government level. Both the political and administrative spheres of municipalities are besieged with corruption, patronage, factions, political appointments of local government officials, subversion of professional ethics and constant party political interference.

Olver's insider account is able to take us through the journey that led to the ANC's dismal loss in local government elections in 2016 as a political party that had enjoyed an overwhelming majority in most local government councils. His book cleverly manages to use an embedded case study of Nelson Mandela Bay Metropolitan Municipality - a municipality deeply troubled and fractured by ANC

DOI: https://doi.org/10.5130/cjlg.vi23.7532

Article History: Received 01/11/20; Accepted 02/11/20; Published 22/12/20

Citation: Commonwealth Journal of Local Governance 2020, 23: 7532, - https://doi.org/10.5130/cjlg.vi23.7532

(C) 2020 Thina Nzo. This is an Open Access article distributed under the terms of the Creative Commons Attribution 4.0 Unported (CC BY 4.0) License (https://creativecommons.org/licenses/by/4.0/), allowing third parties to copy and redistribute the material in any medium or format and to remix, transform, and build upon the material for any purpose, even commercially, provided the original work is properly cited and states its license. 
internal factional politics - to demonstrate the inner workings of council and administrative politics, mayoral leadership, municipal union politics and local party politics outside the council chamber, and connect these with wider provincial and national party politics. The problems echoed by Olver at Nelson Mandela Bay Municipality can be projected to the wider set of institutional problems faced by the majority of municipalities governed by the ANC. The hierarchical ecosystem of national and subnational local party politics provides the reader with a picture of the political complexities and dynamics the municipalities in South Africa operate under. These politics are interwoven with national and local factional politics of the ANC ruling party, which asphyxiate the life and breath of municipal governance and accountability.

While it may be argued that Nelson Mandela Bay Municipality as an embedded institutional case study is located within a local context and its local politics, on the other hand this book reminds us of the symbiotic inter-dependency of national and subnational politics and how municipal institutions are (re)shaped by both local and national politics of the day. State capture and grand scale corruption which implicated the former President Jacob Zuma and his allies in the ANC, who were connected with dubious prominent business people, have become a national political focus that has reshaped the characteristics of political-administrative state relations in South Africa. However, the attention to state capture at national level has tended to overlook how such relations also influence subnational politics and its proximal local government institutions that are dominated by prominent local party elites and local business people who sought to capture the local state and its resources.

Therefore, this book manages to slice through the layer cake of ANC factional politics from national to local level and crystalises these factions within state capture from 'below' at local government level, by linking it to the entangled relationship between local ANC party politics, council politics and the municipal administration. The book manages to illuminate how local political elites wield political power and authority through the formation of relationships with dubious local business people with particularistic interests - thus managing to capture the local state by weaving a pathological web of patronage and corruption into the administration of the municipality.

More importantly, the book moves beyond the political sphere into the administration of the municipality, attempting to demonstrate how municipal officials are also captured by local political elites and business people, turning them into complicit bureaucrats, to the extent where they are able to use their bureaucratic power to facilitate corruption on behalf of their political principals and factional leaders. 
Crispian Olver's book makes a unique contribution to the local literature on ANC party politics and local government. He is able to make an explicit connection between ANC party politics and council politics, something that authors who have written about local government politics in South Africa have not be able to achieve. Olver shows how the external ANC party politics of local government impact on municipal council politics and why it is important for ANC local politicians to get into positions of power in subnational ANC regional party structures. Party factional divisions in the run-up to local government elections and ANC regional party elections provide an opportunity to gain access to political party power in order to wield authority over control of municipal resources. He also takes us into the clandestine world of political funding at local government level, revealing how political control over the distribution of municipal resources can help fund party political campaigns of factional groups, while business people on the other hand are able to provide financial support to prospective mayoral candidates and factional alliances during the elections in order to secure business deals with the municipality in return.

Secondly, Olver manages to draw our attention to the problems associated with ANC practices of political appointments of senior municipal officials into the administration. Patronage appointments are often used by ANC party officials to nurture a foundation for financially and mutually beneficial relationships underpinned by corruptive practices. Political relations between municipal officials with prominent political local elites in ANC party structures outside the municipality are largely motivated by self-preservation and the need to secure hierarchical political protection from facing legal sanctions and consolidate access to resources.

In Nelson Mandela Bay Municipality, we can see how political and social networks between key local ANC party politicians and local business people outside the municipality provide an enabler for financial irregularities and subversion of the law. This brings us closer to another dimension in the inner workings of political and administrative interfaces by demonstrating how the lines between politics and administration are not always clear-cut. Olver's honest and frank reflections of how he delved into party politics imply that a grey zone often exists. His reflections on his own partisan positionality demonstrate the dilemmas faced by politically appointed municipal officials who constantly have to navigate and seamlessly intersect between the two worlds of politics and administration. Municipal officials often get pulled into the world of party politics, which does have an implication on their ability to uphold professional norms and values.

Thirdly, this book demonstrates that control and power are unevenly dispersed at various levels of the municipal institution - giving the dominant presence of rogue and powerful bureaucrats in municipal 
institutions above politicians. Through 'the rent-a-protest' presented in chapter 8 , we can see how municipal officials are able to manipulate the allocation of resources for housing development projects by artificially creating a housing demand. While understanding that patron-client relations permeate between elected representatives and their communities, this book interestingly shows how partisan municipal officials can equally wield local power by playing politics in framing service delivery protests to reinforce patron-client relations in local communities for their personal gain.

The proliferation of a rogue municipal bureaucracy in the housing department, supply chain and budget and treasury department who are in cahoots with local business people on the other hand, also introduces a different patron-client network in the bureaucracy. The book also manages to articulate that corruption at local government level exists within an ecosystem of co-dependency between communities, local politicians, municipal officials and business people. Thus in this ecosystem, information about financial irregularities and corruption is then also used by municipal officials as currency to bargain with implicated ANC party officials for their protection from facing legal sanctions that may be enforced by political office bearers in the municipality.

In spite of the incredible effort made by the book in bringing together the complex world of politics and administration in local government, nevertheless it falls short in providing an analytical gaze into the relationship between the party and the state through the prism of party politics and representation. It fails to explicitly illuminate its implications on democracy in correlation with the diminishing voter support for ANC and its elected representatives. This could have been better presented in order to tell us more about the local government state by having dialogue with other authors who have previously attempted to write about party-state relations in South Africa.

The beginning of the book attempts unsuccessfully to provide a brief historical background to previous intervention attempts made by national government to 'fix' local government since its inception years in post-apartheid South Africa. This would have provided the reader with a context into the problematic history of knee-jerk local government in South Africa which led to the adoption of the 'Back to Basic' reforms and Olver's clean-up assignment at Nelson Mandela Bay Municipality. Olver could have presented the ways in which Nelson Mandela Bay as a municipality was not unique in terms of demonstrating the fragile state of local government in South Africa. By drawing on these post-apartheid historical processes of local government reforms, readers would have better understood why local government has been marked by precarious politics, instability, fragility and dysfunctionality compared to other national and provincial spheres of government. 
Nevertheless, the book outstandingly describes, in an insightful, intimate and dramatic way, how patronage and corruption in municipalities have penetrated and pervaded political governance eroding a much needed bureaucratic capacity in local government, thus delivering the kind of 'dysfunctionality' that has been exposed in Olver's book. Unarguably, for those who want to understand the ANC's electoral decline in local government, this book highlights the consequences of the persistent pathological presence of patronage and corruption which ultimately contributed to ANC's electoral loss of strategic city governments beyond Nelson Mandela Bay Municipality in the 2016 local government elections.

\section{Declaration of conflicting interest}

The author declared no potential conflicts of interest with respect to the research, authorship, and/or publication of this article.

\section{Funding}

The author received no financial support for the research, authorship, and/or publication of this article. 